\title{
DOE/me/26288--24
}

\section{Sonic-Enhanced Ash Agglomeration and Sulfur Capture}

\author{
Technical Progress Report \\ July - September 1997
}

RECEIVED

JUN 291998

OSTI

Work Performed Under Contract No.: DE-AC21-89MC26288

For

U.S. Department of Energy

Office of Fossil Energy

Federal Energy Technology Center

P.O. Box 880

Morgantown, West Virginia 26507-0880

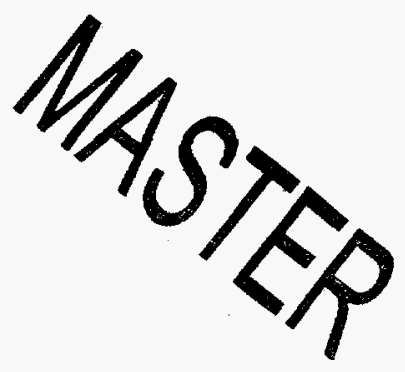

By
Manufacturing and Technology Conversion International, Inc.

P. O. Box 21

Columbia, Maryland 21045-0021 


\section{Disclaimer}

This report was prepared as an account of work sponsored by an agency of the United States Government. Neither the United States Government nor any agency thereof, nor any of their employees, makes any warranty, express or implied, or assumes any legal liability or responsibility for the accuracy, completeness, or usefulness of any information, apparatus, product, or process disclosed, or represents that its use would not infringe privately owned rights. Reference herein to any specific commercial product, process, or service by trade name, trademark, manufacturer, or otherwise does not necessarily constitute or imply its endorsement, recommendation, or favoring by the United States Government or any agency thereof. The views and opinions of authors expressed herein do not necessarily state or reflect those of the United States Government or any agency thereof. 


\section{DISCLAIMER}

Portions of this document may be illegible electronic image products. Images are produced from the best available original document. 


\section{PREFACE}

This 33rd Quarterly Technical Progress Report presents the results of work accomplished during the period June 30, 1997 - October 05, 1997 (July, August and September) under Contract No. DE-AC21-88MC26288 entitled "Sonic Enhanced Ash Agglomeration and Sulfur Capture."

During this reporting period, a time extension for the contract at no additional cost to the Department of Energy was requested. The request was granted and the period of performance was extended to March 31, 1998. 


\section{TABLE OF CONTENTS}

Page

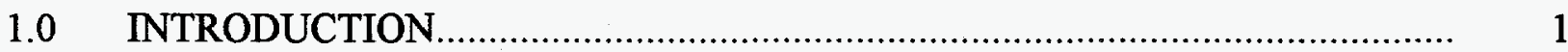

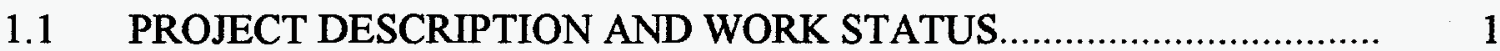

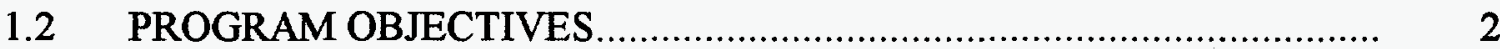

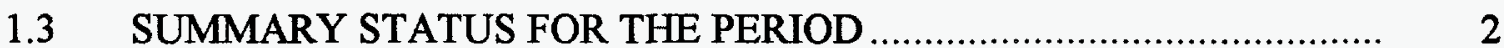

2.0 TECHNICAL DISCUSSION OF THE WORK ACCOMPLISHED DURING THE REPORTING PERIOD

2.1 TASK 2: ADDITIONAL TEST FACILITY MODIFICATIONS AND SHAKEDOWN TESTING

2.2 TASK 5: COMMERCIALIZATION PLAN ...................................... 3

3.0 PLANS FOR NEXT PERIOD 


\section{SECTION 1.0}

\section{INTRODUCTION}

\subsection{PROJECT DESCRIPTION AND WORK STATUS}

A major concern with the utilization of coal in directly fired gas turbines is the control of particulate emissions and reduction of sulfur dioxide, and alkali vapor from combustion of coal, upstream of the gas turbine. Much research and development has been sponsored on methods for particulate emissions control and the direct injection of calcium-based sorbents to reduce $\mathrm{SO}_{2}$ emission levels. The results of this research and development indicate that both acoustic agglomeration of particulates and direct injection of sorbents have the potential to become a significant emissions control strategy.

The Sonic Enhanced Ash Agglomeration and Sulfur Capture program focuses upon the application of an MTCI proprietary invention (Patent No. 5,197,399) for simultaneously enhancing sulfur capture and particulate agglomeration of the combustor effluent. This application can be adapted as either a "hot flue gas cleanup" subsystem for the current concepts for combustor islands or as an alternative primary pulse combustor island in which slagging, sulfur capture, particulate agglomeration and control, and alkali gettering as well as $\mathrm{NO}_{\mathrm{x}}$ control processes become an integral part of the pulse combustion process.

The goal of the program is to support the DOE mission in developing coal-fired combustion gas turbines. In particular, the MTCI proprietary process for bimodal ash agglomeration and simultaneous sulfur capture will be evaluated and developed. The technology embodiment of the invention provides for the use of standard grind, moderately beneficiated coal and WEM for firing the gas turbine with efficient sulfur capture and particulate emission control upstream of the turbine. The process also accommodates injection of alkali gettering material if necessary. This is aimed at utilization of relatively inexpensive coal fuels, thus realizing the primary benefit being sought by direct firing of coal in such gas turbine systems. The proposed technology provides for practical, reliable, and capital (and O\&M) cost-effective means of protection for the gas turbine from impurities in the coal combustor effluent. 


\subsection{PROGRAM OBJECTIVES}

The major objective of the Phase I test program is to confirm the feasibility of the MTCI bimodal particle size approach to enhance particulate control by acoustic ash agglomeration. An ancillary objective of the Phase I effort is to demonstrate and confirm the feasibility of an acoustic field to enhance sulfur capture by increasing sorbent reactivity. Phase I tests are designed to cover the frequency range between 50 and $1400 \mathrm{~Hz}$, establish monomodal baseline performance as a benchmark from which to measure the degree of enhancement expected from the bimodal approach, and, finally, to confirm the effectiveness of low-frequency fields over high-frequency fields for realistic particulate streams.

The program will demonstrate the effectiveness of a unique approach which uses a bimodal distribution composed of large sorbent particles and fine fly ash particles to enhance ash agglomeration and sulfur capture at conditions found in direct coal-fired turbines. Under the impact of high-intensity sound waves, sorbent reactivity and utilization, it is theorized, will increase while agglomerates of fly ash and sorbents are formed which are readily collected in commercial cyclones. The work will extend the concept from the demonstration of feasibility (Phase I), through proof-of-concept (Phase II) to the construction (Phase III) of a coal-fired pulsed combustor with in-furnace sorbent injection. For Phase I, Pennsylvania State University will conduct studies for enhanced sulfur capture in The Combustion Laboratory and agglomeration tests in the High Intensity Acoustic Laboratory.

\subsection{SUMMARY STATUS FOR THE PERIOD}

During this reporting period, commercialization activity was continued. Also, a time extension for the contract at no additional cost to the Department of Energy was requested. The request was granted and the period of performance was extended to March 31, 1998. 


\section{SECTION 2.0 \\ TECHNICAL DISCUSSION OF THE WORK ACCOMPLISHED DURING THE REPORTING PERIOD}

\subsection{TASK 2: ADDITIONAL TEST FACILITY MODIFICATIONS}

AND SHAKEDOWN TESTING

No activity during this reporting period.

\subsection{TASK 5: COMMERCIALIZATION PLAN}

No activity during this reporting period. 


\section{SECTION 3.0}

\section{PLANS FOR NEXT PERIOD}

- Complete the fabrication of the slag handling section, ash drain section and the second-level structural support.

- Pursue commercialization activities.

- $\quad$ Prepare a Final Report. 